УДК 343.137 .9

DOI https://doi.org/10.32837/pyuv.v0i4(39).916

M.I. Дерев'янко

orcid.org/0000-0003-4239-9286

кандидат юридичних наук,

асистент кафедри кримінального процесу та криміналістики

Інституту права Київського національного університету імені Тараса Шевченка

\title{
ПРОБЛЕМИ НАДАННЯ НЕОБГРУНТОВАНИХ ПЕРЕВАГ ПІД ЧАС ВИКОРИСТАННЯ ОСОБЛИВОГО ПОРЯДКУ КРИМІНАЛЬНОГО ПРОВАДЖЕННЯ
}

Аналіз положень кримінального процесуального законодавства України та правозастосовної практики свідчить про те, що в нашій країні деякі особи через належність до певної професії та займану посаду мають більший обсяг гарантій своїх прав, ніж пересічні громадяни. Так, у главі 37 Кримінального процесуального кодексу України (далі - КПК) передбачені особливості кримінального провадження щодо окремої категорії осіб. Своєю чергою у ст. 10 КПК України закріплено, що не може бути привілеїв чи обмежень у процесуальних правах, передбачених цим Кодексом, за ознаками раси, кольору шкіри, політичних, релігійних чи інших переконань, статі, етнічного та соціального походження, майнового стану, місця проживання, громадянства, освіти, роду занять, а також за мовними або іншими ознаками. Таким чином, у КПК України існують суперечливі між собою положення щодо здійснення кримінального провадження, а тому актуальним є дослідження питань, пов'язаних із забезпеченням рівності громадян перед законом і судом під час використання особливого порядку кримінального провадження, передбаченого главою 37 КПК України.

Наукові дослідження, присвячені розробці проблем забезпечення прав і свобод особи у кримінальному судочинстві, здійснювали Л.Д. Воєводін, А.П. Горшеньов, С.Ю. Ільченко, В.І. Камінська, В.М. Корнуков, Л.О. Красавчикова, О.А. Лукашева, П.І. Люблінський, В.І. Маринів, Г.Д. Мепарішвілі, І.В. Михайловський, М.М. Михеєнко, І.Л. Петрухін, М.А. Погорецький, М.М. Полянський, А.Л. Рівлін, Ф.М. Рудинський, І.Є. Фарбер, I.Я. Фойницький, А.Л. Ципкін, Г.І. Чангулі, I.О. Шумак, М.Є. Шумило та інші учені. При цьому питання, які стосуються реалізації гарантій рівності громадян перед законом і судом під час використання особливого порядку кримінального провадження, не втратили своєї актуальності й дотепер. Зважаючи на це, метою публікації $\mathrm{e}$ дослідження наслідків застосування особливого порядку кримінального провадження, зокрема встановлення, чи призводить воно до надання необгрунтованих переваг певним особам, залежно від їхньої професії та займаної посади.
У Конституції України проголошується, що всі люди є вільними та рівними у своїй гідності і правах, а також, що громадяни мають рівні конституційні права і свободи та є рівними перед законом. В Основному Законі наголошено, що не може бути привілеїв чи обмежень за ознаками раси, кольору шкіри, політичних, релігійних та інших переконань, статі, етнічного і соціального походження, майнового стану, місця проживання, за мовними або іншими ознаками (ст. 21,24 Конституції України). Таким чином, у законодавстві нашої країни задекларовано правові гарантії інституту рівноправ'я та надано класифікацію основних порушень рівності прав і свобод особи за різними ознаками. Ідея рівноправ'я знайшла належне закріплення у ст. 10 КПК України. Водночас у законодавстві нашої країни містяться положення, завдяки яким окремі фізичні особи для забезпечення виконання ними соціально корисних функцій у передбачених випадках звільняються від обов'язків та юридичної відповідальності. Такі положення, зокрема, містяться:

- у ст. 105 Конституції України, ст. 9 Закону України «Про Президента Української РСР»;

- у ст. 80 Конституції України, ст. 27 Закону України «Про статус народного депутата України»;

- у ст. 31 Закону України «Про статус депутатів місцевих рад»;

- у ст. 20 Закону України «Про Уповноваженого Верховної Ради України з прав людини»;

- у ст. 149 Конституції України, ст. 24 Закону України «Про Конституційний Суд України»;

- у ст. 126 Конституції України, ст. 48 Закону України «Про судоустрій і статус суддів»;

- у ст. 9 Закону України «Про запобігання корупції»;

- у ст. 29, 31 Віденської конвенції про дипломатичні зносини від 18 квітня 1961 р., ратифікованої Указом Президії ВР СРСР від 11 лютого 1964 р. та Указом Президії ВР УРСР від 21 березня 1964 р.;

- у ст. 23 Закону України «Про адвокатуру та адвокатську діяльність».

Відповідні гарантії, або, як уточнюють вчені, «особливий правовий режим за рахунок додаткових прав та обов'язків» $[1$, с. 189], передусім спрямовані на забезпечення належного виконання 
певними суб'єктами покладених на них соціально корисних функцій. Безпідставне притягнення до юридичної відповідальності чи порушення стану недоторканності є тими видами зазіхань, які, на думку законодавця, здатні завадити деяким особам виконувати покладені на них обов'язки.

Своєю чергою наявність і використання особливого порядку кримінального провадження, який застосовується до осіб певної професії та займаної посади, надає останнім очевидні переваги, порівняно з іншими. Такі переваги, зокрема, пов'язуються з визначенням:

- Генерального прокурора (виконувача обов' язків Генерального прокурора) відповідальним за дотримання законності під час внесення відомостей до Єдиного реєстру досудових розслідувань, а також за своєчасне повідомлення Верховного Суду про початок досудового розслідування стосовно судді Вищого антикорупційного суду (ч. 1, 2 ст. 480-1 КПК України);

- Генерального прокурора або його заступника чи керівника обласної прокуратури відповідальним за здійснення письмового повідомлення про підозру стосовно адвоката, депутата місцевої ради, депутата Верховної Ради Автономної Республіки Крим, сільського, селищного, міського голови (п. 1 ч. 1 ст. 481 КПК України);

- Генерального прокурора (виконувача обов'язків Генерального прокурора) або заступника Генерального прокурора - керівника Спеціалізованої антикорупційної прокуратури, відповідальним за здійснення письмового повідомлення про підозру стосовно народного депутата України, кандидата у Президенти України, Уповноваженого Верховної Ради України з прав людини, Голови або іншого члена Рахункової палати, прокурора Спеціалізованої антикорупційної прокуратури, Директора або іншого працівника Національного антикорупційного бюро України, заступників Генерального прокурора, Голови Національного агентства з питань запобігання корупції, його заступника (п. 2 ч. 1 ст. 481 КПК України);

- Генерального прокурора або його заступника відповідальним за здійснення письмового повідомлення про підозру стосовно судді, судді Конституційного Суду України, присяжного на час виконання ним обов'язків у суді, Голови, заступника Голови, члена Вищої ради правосуддя, Голови, заступника Голови, члена Вищої кваліфікаційної комісії суддів України, працівників Національного антикорупційного бюро України (п. 3 ч. 1 ст. 481 КПК України);

- Генерального прокурора (виконувача обов'язків Генерального прокурора) відповідальним за здійснення письмового повідомлення про підозру стосовно судді Вищого антикорупційного суду (п. 3-1 ч. 1 ст. 481 КПК України);
- заступника Генерального прокурора відповідальним за здійснення письмового повідомлення про підозру стосовно Генерального прокурора (п. 4 ч. 1 ст. 481 КПК України);

- Вищої ради правосуддя органом, уповноваженим надавати або не надавати згоду на затримання чи утримання під вартою судді або арешт до винесення обвинувального вироку судом, за винятком затримання судді під час або одразу ж після вчинення тяжкого чи особливо тяжкого злочину (ч. 1 ст. 482 КПК України);

- слідчого судді, який визначений п. 18 ч. 1 ст. 3 КПК України, відповідальним за розгляд клопотань учасників кримінального провадження під час досудового розслідування в кримінальному провадженні щодо судді Вищого антикорупційного суду (ст. 482-1 КПК України);

- Генерального прокурора (особи, що виконує обов'язки Генерального прокурора) відповідальним за дотримання законності під час внесення відомостей до Єдиного реєстру досудових розслідувань, що можуть свідчити про вчинення кримінального правопорушення народним депутатом України (ч. 1 ст. 482-2 КПК України);

- Генерального прокурора (особи, що виконує обов'язки Генерального прокурора) відповідальним за погодження або непогодження клопотання про дозвіл на затримання, обрання запобіжного заходу у вигляді тримання під вартою чи домашнього арешту, обшук, порушення таємниці листування, телефонних розмов, телеграфної та іншої кореспонденції, а також про застосування інших заходів, зокрема негласних слідчих (розшукових) дій, що, відповідно до закону, обмежують права і свободи народного депутата України (ч. 1 ст. 482-2 КПК України);

- органу або посадових осіб, які затримали, повідомили про підозру або застосували запобіжний захід чи здійснили інші слідчі дії стосовно народного депутата України чи Голови Верховної Ради України, відповідальними за повідомлення про це керівництва Верховної Ради України (ч. 2 ст. 482-2 КПК України).

Таким чином, у разі застосування чи загроз застосування обмежень до осіб, визначених у ст. 480 КПК України, повинні вживатися конкретні заходи, спрямовані на унеможливлення безпідставного притягнення їх до юридичної відповідальності. Закріплення у законодавстві та застосування відповідних заходів суттєво покращують процесуальне становище окремих осіб, порівняно зі становищем пересічних громадян. Такі переваги є допустимими за умови, якщо вони не вважаються дискримінацією.

У ч. 2 ст. 6 Закону України «Про засади запобігання та протидії дискримінації в Україні» передбачені умови, за наявності яких певні позитивні дії щодо окремих осіб не є дискримінацією. Так, 
дискримінацією не вважаються дії, які не обмежують права та свободи інших осіб і не створюють перешкод для їх реалізації, а також не надають необгрунтованих переваг особам та (або) групам осіб за їх певними ознаками, щодо яких застосовуються позитивні дії, а саме:

- спеціальний захист державою окремих категорій осіб, які потребують такого захисту;

- здійснення заходів, спрямованих на збереження ідентичності окремих груп осіб, якщо такі заходи необхідні;

- надання пільг і компенсацій окремим категоріям осіб у випадках, передбачених законом;

- встановлення державних соціальних гарантій окремим категоріям громадян;

- особливі вимоги, передбачені законом, щодо реалізації прав окремих категорій осіб.

Очевидно, що передбачені особливостями кримінального провадження дії щодо окремої категорії осіб не містять тих ознак, які вказані у ч. 2 ст. 6 Закону України «Про засади запобігання та протидії дискримінації в Україні», адже вони за своїм змістом не є позитивними діями у розумінні п. 5 ч. 1 ст. 1 вказаного Закону. В разі перебування осіб, визначених ст. 480 КПК України, у порівняно схожій ситуації з іншими особами, наприклад у межах одного кримінального провадження, можна вести мову про наявність ознак дискримінації, адже очевидною буде різниця у поводженні.

Слід зауважити, що разом із положеннями, в яких закріплено очевидну різницю у ставленні до осіб, залежно від їхньої професії та займаної посади, глава 37 КПК України містить також положення, які відображають приховану дискримінацію. Так, у ч. 2 ст. 482-1 КПК України зазначається, що розгляд клопотань про застосування заходів, котрі, відповідно до закону, обмежують права і свободи народного депутата України, розгляд яких віднесено до повноважень слідчого судді, здійснюється за обов'язковою участю народного депутата України. При цьому слідчий суддя зобов'язаний завчасно повідомити народного депутата України про розгляд зазначеного клопотання, крім клопотання про застосування негласних слідчих (розшукових) дій або обшуку. Таким чином, розгляд клопотань без участі народного депутата є порушенням вимог ч. 2 ст. 482-1 КПК України та може призвести до визнання доказів недопустимими або визнати застосування заходів забезпечення кримінального провадження незаконним. Своєю чергою ч. 2 ст. 172 КПК України передбачено, що клопотання слідчого, прокурора, цивільного позивача про арешт майна, яке не було тимчасово вилучене, може розглядатися без повідомлення підозрюваного, обвинуваченого, іншого власника майна, їх захисника, представника чи законного представника, представника юридичної особи, щодо якої здійснюється провадження, якщо це є необхідним з метою забезпечення арешту майна.

Очевидно, що в разі розгляду клопотання про арешт майна народного депутата України такий розгляд, відповідно до ч. 2 ст. 482-1 КПК України, буде відбуватися за обов'язковою участю відповідної особи, яка про нього буде завчасно повідомлена, на відміну від розгляду клопотання про арешт майна інших осіб, які не мають статусу народного депутата.

Завдяки перевазі у ставленні право народного депутата України, передбачене ст. 41 Конституції України, буде більш захищеним, порівняно 3 іншими особами. Так, суб'єкти кримінального провадження зі статусом народного депутата завчасно будуть повідомлятися про розгляд клопотань щодо арешту майна, за бажанням завжди зможуть бути присутніми під час їх розгляду. Через це таких осіб не буде позбавлено права надавати пояснення, заявляти клопотання, пред'являти докази на захист своєї власності, оперативно оскаржувати заходи забезпечення кримінального провадження тощо. Пересічні громадяни, щодо майна яких вирішуватиметься питання про арешт, таких можливостей не матимуть.

У п. 6 ч. 1 ст. 1 Закону України «Про засади запобігання та протидії дискримінації в Україні» зазначено, що ситуація, за якої з особою та (або) групою осіб через їх певні ознаки поводяться менш прихильно, ніж з іншою особою та (або) групою осіб в аналогічній ситуації, крім випадків, коли таке поводження має правомірну, об’єктивно обгрунтовану мету, способи досягнення якої є належними та необхідними, вважається прямою дискримінацією.

Правомірна, об'єктивно обгрунтована мета, способи досягнення якої є належними та необхідними, визначається в аспекті вчинення позитивних дій, про які йдеться у п. 5 ч. 1 ст. 1 Закону України «Про засади запобігання та протидії дискримінації в Україні». Відповідно до цього визначення обгрунтована мета пов'язується виключно з усуненням юридичної чи фактичної нерівності у можливостях, що ніяк не стосується надання комусь додаткових переваг.

Якщо спрогнозувати ситуацію, коли в одному кримінальному провадженні до сфери кримінального судочинства будуть залучені декілька осіб одного процесуального статусу i серед них буде народний депутат України, то в разі застосування заходів забезпечення кримінального провадження до всіх цих осіб матиме місце пряма дискримінація. Адже очевидними стануть переваги становища народного обранця над іншими, який не буде позбавлений під час судового розгляду права доступу до правосуддя.

Вченими визначено алгоритми побудови аргументації щодо наявності дискримінації, зокрема 
зауважується, що така побудова відбувається поетапно. До цих етапів належить: 1) ідентифікація неоднакового поводження чи ставлення; 2) пошук або вибір компаратора; 3) визначення та доведення ознаки розрізнення у поводженні; 4) оцінка становища «жертви», порівняно з компаратором; 5) перевірка наявності легітимної мети запроваджуваних заходів; 6) перевірка пропорційності заходів, зокрема, чи досягається мета вжитими заходами, чи можна було досягти тієї ж мети у менш обтяжливий спосіб, чи не була перейдена межа свободи розсуду держави [2, с. 82].

Ідентифікація неоднакового поводження чи ставлення в разі застосування особливого порядку кримінального провадження має відбуватися на підставі аналізу положень ст. 480-483 КПК України з урахуванням єдиного процесуального статусу жертви дискримінації та особи, визначеної у ст. 480 КПК України. Відповідне порівняння стану осіб, які в одному кримінальному провадженні перебувають в однаковому процесуальному статусі, видається логічним. Як справедливо зазначають С.А. Заєць та P.Ю. Мартиновський, особи, яких обрано для порівняння, або компаратори, мають перебувати в аналогічному або максимально схожому стані [3, с. 7].

Незважаючи на встановлення ознак дискримінації через надання необгрунтованих переваг під час застосування особливого порядку кримінального провадження, слід зауважити, що наразі це встановлення до жодних юридичних наслідків не призведе. Причиною такого скептичного, але об'єктивного висновку є те, що положення про дискримінацію закріплені безпосередньо в КПК України. Без їх скасування звернення, наприклад до Уповноваженого Верховної Ради України з прав людини, завершиться отриманням звичайної відписки, а судове оскарження не матиме жодної перспективи.

Закон України «Про засади запобігання та протидії дискримінації в Україні» набув чинності 4 жовтня 2012 р. Своєю чергою КПК України був прийнятий 13 квітня 2012 р., а тому його антидискримінаційна експертиза не проводилася. При цьому ухвалені в подальшому норми, якими була змінена та доповнена глава 37 КПК України, також лишалися без належної уваги органів, уповноважених на проведення експертизи, здебільшого через те, що суб'єктом подання проєктів змін до положень КПК України були народні депутати, а проведення антидискримінаційної експертизи покладено на органи виконавчої влади.

У главі 37 КПК України наведені особливості кримінального провадження щодо окремої категорії осіб. Водночас ці особливості містять положення, якими передбачені додаткові процесуальні гарантії забезпечення прав осіб, посади яких визначені у ст. 480 КПК України. Наявність у КПК України додаткових гарантій та їх реалізація під час досудового розслідування свідчать про існування підстав для дискримінації інших осіб, які не вказані у ст. 480 КПК України. Глава 37 КПК України, як і положення всього Кодексу, потребують проведення антидискримінаційної експертизи з метою встановлення їх відповідності принципу недискримінації. 3 огляду на викладене видаються надзвичайно актуальними подальші наукові розвідки у сфері кримінального судочинства з проблем запобігання дискримінації за професійною, майновою та іншими ознаками.

\section{Jimepamypa}

1. Аскеров С.С. Особливий порядок кримінального провадження щодо присяжного і народного засідателя. Юридичний науковий електронний журнал. 2014. № 6. C. $186-189$.

2. Савчин M.B. «CARELESS WHISPER» Конституційного Суду України та конституційні цілі. Український часопис конституиійного права. 2020. № 4. С. 72-89.

3. Практичний посібник із аргументації у справах щодо дискримінації / упоряд.: С.А. Заєць, Р.Ю. Мартиновський. Страсбург : Рада Європи, 2015. 72 с.

\section{Анотація}

Дерев'янко М. I. Проблеми надання необгрунтованих переваг під час використання особливого порядку кримінального провадження. - Стаття.

У статті розкриваються проблеми забезпечення прав і свобод особи у кримінальному судочинстві під час застосування особливого порядку кримінального провадження, передбаченого главою 37 Кримінального процесуального кодексу України. Актуальність публікації зумовлена вразливістю правового статусу особи, залученої до сфери кримінального судочинства, а також мінливістю його обсягу, залежно від певних обставин. Метою публікації $є$ дослідження наслідків застосування особливого порядку кримінального провадження, з'ясування, чи призводить воно до необгрунтованих переваг одних суб'єктів кримінального провадження над іншими, залежно від професії та займаної посади. Передумовами до формування такої мети стали сучасні проблеми, які виникають під час забезпечення прав і свобод особи. Робота виконана на підставі використання загальнонаукових та спеціальних методів наукового пізнання. Із загальнонаукових, зокрема, використовувалися системно-структурний метод і метод функціонального аналізу, а зі спеціальних - формально-юридичний, логіко-процесуальний методи, метод порівняльного правознавства. Проаналізовано основні законодавчі норми, якими закріплені гарантії забезпечення належного виконання певними суб'єктами покладених на них соціально корисних функцій, а також особливий порядок кримінального провадження, який застосовується до осіб певної професії. У статті зазначено, що наявність у КПК України додаткових гарантій та їх реалізація під час досудового розслідування свідчать про існування підстав для дискримінації інших осіб, які не вказані у ст. 480 КПК України. Глава 37 КПК України, як і положення всього Кодексу, потребують проведення антидискримінаційної експертизи з метою встановлення їх відповідності принципу недискримінації.

Ключові слова: антидискримінаційна експертиза, гарантії, дискримінація, особливості кримінального провадження щодо окремої категорії осіб, особливий порядок кримінального провадження. 


\section{Summary}

Derevyanko M. I. Problems of providing unjustified advantages during the use of a special procedure for criminal proceedings. - Article.

The article reveals the problems of ensuring the rights and freedoms of a person in criminal proceedings during the application of a special procedure for criminal proceedings provided for in Chapter 37 of the Criminal Procedure Code of Ukraine. The relevance of the publication is due to the vulnerability of the legal status of a person involved in the sphere of criminal proceedings, as well as the variability of its scope, depending on certain circumstances. The purpose of the publication was to study the consequences of using a special procedure for criminal proceedings, to determine whether it leads to unjustified advantages of some subjects of criminal proceedings over another, depending on the profession and position held. The prerequisites for the formation of this goal were modern problems that arise in ensuring the rights and freedoms of individuals. The work was carried out on the basis of the use of general scientific and special methods of scientific knowledge. Among the general scientific methods, in particular, the systemstructural method and the method of functional analysis were used, and among the special ones - formal-legal, logical-procedural methods, the method of Comparative Law. The main legislative norms that provide guarantees for ensuring the proper performance of certain subjects assigned socially useful functions, as well as a special procedure for criminal proceedings applied to persons of a certain profession, are analyzed. The article states that the existence of additional guarantees in the Criminal Procedure Code of Ukraine and their implementation during pre-trial investigation indicate the existence of grounds for discrimination against other persons, which are not specified in Article 480 of the Criminal Procedure Code of Ukraine. Chapter 37 of the Criminal Procedure Code of Ukraine, as well as the provisions of the entire code, require an anti-discrimination expert examination in order to establish their compliance with the principle of non-discrimination.

Key words: anti-discrimination expertise, guarantees, discrimination, features of criminal proceedings against a certain category of persons, special procedure for criminal proceedings. 